Jurnal Ilmu Ilmu Agribisnis: Journal of Agribusiness Science, 9(4), November 2021

\title{
KEPUTUSAN, SIKAP, DAN FAKTOR - FAKTOR YANG MEMENGARUHI PEMBELIAN TELUR AYAM RAS PADA RUMAH TANGGA PRASEJAHTERA
}

\author{
(Decisions, Attitudes and Affecting Factors on The Purchase of Chicken Eggs \\ by Underprivileged Households)
}

Andika Prasetio Nugroho, Yaktiworo Indriyani, Wuryaningsih Dwi Sayekti

Jurusan Agribisnis, Fakultas Pertanian, Universitas Lampung, Jl. Prof Dr. Soemantri Brojonegoro No.1

Bandar Lampung, e-mail: yaktiworo.indriani@fp.unila.ac.id

\begin{abstract}
This study aimed to determine the decision making, attitudes and factors that affected underprivileged households on buying eggs in Bandar Lampung city. This research was conducted in Teluk Betung Timur. The research method used in this research was survey method. The research data consisted of primary and secondary data. Primary data was collected by conducting interviews with 75 underprivileged households. Secondary data was obtained by literature study. The sampling technique used in this study was simple random sampling. The research data was analyzed descriptively and qualitatively, by Fishbein multiattribute model and multiple linear regression analysis. The results obtained from this study showed that consumers decided to buy eggs at the sales location through the need recognition stage, information search stage, alternative evaluation stage, purchase decision stage and post purchase evaluation stage. The price of chicken eggs was the benefit, main focus and the most considered on choosing a location to buy eggs. Consumers prefer buying eggs at grocery stalls compared to traditional markets and modern markets. Together, the price of eggs, household income, number of household members, the price of free-range chicken eggs, the price of purebred chicken, the price of beef, the price of tempeh, tofu, salted fish and cooking oil had a significant effect on purchasing eggs. Factors that significantly influence the purchase of eggs by underprivileged households in Bandar Lampung were the price of eggs and the number of household members.
\end{abstract}

Key words: attitude, decision, eggs, factors

\section{PENDAHULUAN}

Sektor pertanian memiliki peran yang penting untuk mencukupi kebutuhan pangan masyarakat. Peternakan merupakan satu diantara banyak subsektor pada pertanian yang memegang peran besar dalam pertumbuhan ekonomi Indonesia. Peran ini ditinjau dari fungsi hasil peternakan sebagai sumber protein hewani (daging dan telur) untuk mencukupi atau melengkapi kebutuhan gizi masyarakat. Telur ayam ras memiliki harga yang paling rendah jika dibandingkan dengan telur ayam kampung, daging ayam ras dan daging sapi. Hal ini menjadikan telur ayam ras sebagai jenis bahan makanan yang selalu dibutuhkan dan dikonsumsi secara luas oleh masyarakat. Menurut data Badan Pusat Statistik Kota Bandar Lampung tahun 2018, pengeluaran rata - rata masyarakat di Kota Bandar Lampung untuk pembelian telur lebih tinggi jika dibandingkan dengan daging. Pengeluaran untuk pembelian telur sebesar 6,97 persen sedangkan untuk pembelian daging hanya sebesar 4,71 persen.
Tentu saja, hal ini disebabkan karena kandungan gizi telur ayam yang cukup baik serta harganya yang dapat dikatakan relatif rendah, sehingga banyak masyarakat yang lebih memilih utuk mengkonsumsi telur ayam.

Kota Bandar Lampung merupakan pusat aktivitas ekonomi dan bisnis dengan jumlah penduduk sebanyak 1.051.500 jiwa (BPS Kota Bandar Lampung 2018). Oleh karena hal tersebut, Kota Bandar Lampung merupakan wilayah yang memiliki potensi dalam memasarkan produkproduk pertanian. Telur ayam ras yang dipasarkan di Bandar Lampung dapat dengan mudah dijumpai di pasar tradisional, pasar modern dan warung kelontong). Sifat dari telur yang mudah dijumpai, harganya yang murah serta gizi yang cukup baik, telur ayam ras menjadi lauk yang dipilih oleh rumah tangga prasejahtera. Rumah tangga prasejahtera adalah rumah tangga yang belum dapat memenuhi kebutuhan dasar (basic needs) secara minimal, seperti kebutuhan akan sandang, 
pangan papan, kesejahteraan dan pendidikan (Badan Kependudukan dan Keluarga Berencana Nasional Provinsi Lampung 2018).

Dalam membeli telur ayam ras, konsumen melakukan pemilihan untuk membeli telur ayam ras di beberapa lokasi penjualan yang ada, yaitu di pasar tradisional, pasar modern, maupun warung kelontong. Ketiga lokasi penjualan tersebut memiliki kelebihan dan kekurangan yang tentunya menjadi pertimbangan utama konsumen dalam melakukan pembelian telur ayam. Dalam teori perilaku konsumen, sikap merupakan konsep penting yang dapat meramalkan perilaku konsumen. Sikap adalah kecenderungan yang dipelajari dalam berperilaku dengan cara yang menyenangi atau tidak menyenangi terhadap objek tertentu (Schiffman dan Kanuk 2007).

Dalam pembelian telur ayam ras di beberapa lokasi penjualan, konsumen memiliki sikap suka atau tidak suka terhadap atribut- atribut yang dimiliki tiap - tiap lokasi penjualan yang ada. Dalam menentukan pilihan, konsumen bebas membeli telur ayam di beberapa lokasi penjualan yang sesuai dengan selera dan keinginannya. Faktor - faktor yang memengaruhi keputusan pembelian telur ayam ras juga perlu diketahui untuk mengetahui strategi apa yang perlu dilakukan oleh pedagang. Penelitian ini bertujuan untuk mengetahui tahapan pengambilan keputusan rumah tangga dan menganalisis sikap serta menganalisis faktor faktor yang memengaruhi rumah tangga prasejahtera dalam membeli telur ayam ras di Kota Bandar Lampung.

\section{METODE PENELITIAN}

Pada penelitian ini metode penelitian yang digunakan adalah metode survai. Hal ini sesuai dengan penelitian mengenai pembelian sate di Kota Bandar Lampung oleh Sitorus, Murniati dan Rangga (2020). Teknik pengambilan sampel yang digunakan adalah simple random sampling dengan menggunakan metode angka acak dengan bantuan microsoft excel, yaitu kerangka sampel yang telah didapat diurutkan dan dipilih sesuai dengan hasil angka acak yang diperoleh pada masing - masing kelurahan sehingga mendapatkan total 75 responden. Hal ini sesuai dengan penelitian Delila, Indriani dan Situmorang (2015) tentang saus sambal botol. Data yang digunakan pada penelitian ini adalah data primer serta data sekunder. Data primer didapatkan dengan melakukan wawancara kepada 75 responden. Responden pada penelitian ini adalah ibu rumah tangga dan kepala keluarga yang ternasuk kedalam anggota rumah tangga prasejahtera yang bertempat tinggal di Kecamatan Teluk Betung Timur. Data sekunder didapatkan dari beberapa instansi seperti data rumah tangga prasejahtera dari BKKBN dan kantor kelurahan yang ada di Kecamatan Teluk Betung Timur. Kecamatan Teluk Betung Timur dipilih karena kecamatan ini merupakan kecamatan dengan jumlah rumah tangga prasejahtera terbanyak yang ada di Kota Bandar Lampung (BKKBN Provinsi Lampung 2018).

Terlebih dahulu dilakukan uji validitas dan reliabilitas terhadap kuesioner yang digunakan pada penelitian ini. Hal ini sesuai dengan penelitian Andela, Endaryanto dan Adawiyah (2020) yang terlebih dahulu melakukan uji validitas dan reliabilitas untuk menguji atribut pie pisang. Pada penelitian ini, bagian kuesioner yang diuji validitas dan reliabilitasnya adalah atribut - atribut yang digunakan untuk menganalisis sikap konsumen.

Pengujian dilakukan terhadap 30 responden sehingga didapatkan r-tabel sebesar 0,361 dengan $\alpha$ sebesar 0,05. Hasil uji validitas dan reliabilitas dapat dilihat pada Tabel 1. Berdasarkan uji validitas dan reliabilitas yang telah dilakukan diketahui bahwa semua atribut pada penelitian ini adalah valid dan reliabel. Nilai $r$ hitung menunjukkan angka lebih dari $\mathrm{r}$ tabel $(0,361)$ dan Cronbach Alpha menunjukkan nilai diatas 0,6.

Untuk mengetahui tahap - tahap proses pengambilan keputusan pembelian telur ayam ras digunakan metode analisis deskriptif kualitatif. Hal ini sesuai dengan penelitian Rahmawati, Sayekti dan Adawiyah (2018) yang menggunakan metode yang sama untuk mengetahui tahap pengambilan keputusan dalam pemilihan pangan lokal olahan. Untuk menganalisis sikap rumah tangga prasejahtera terhadap pembelian telur ayam ras digunakan metode analisis Multiatribut Fishbein. Hal ini sesuai dengan penelitian Meriza, Lestari dan Soelaiman (2016) yang menggunakan metode Multiatribut Fishbein untuk menganalisis sikap konsumen terhadap teh celup Sariwangi dan Sosro.

Menurut Engel, Blackwell dan Miniard (2006), analisis sikap multiatribut dapat menjadi sumber yang kaya akan informasi yang berguna bagi perencanaan dan tindakan pasar. Selain itu, analisis sikap multiatribut juga bermanfaat dalam pengembangan suatu produk baru. 
Tabel 1. Hasil uji validitas dan reliabilitas

\begin{tabular}{llcc}
\hline \multirow{2}{*}{ No } & \multicolumn{1}{c}{ Atribut } & Tingkat Kepercayaan & Tingkat Kepentingan \\
\cline { 2 - 4 } & Harga Telur & 0,723 & \\
\hline 1 & Bobot Telur & 0,362 & 0,883 \\
2 & Kebersihan Telur & 0,479 & 0,717 \\
3 & 0,633 & 0,566 \\
4 & Kemasan Telur & 0,609 & 0,712 \\
5 & Kesukaan terhadap lokasi & 0,624 & 0,736 \\
6 & Kebersihan Lokasi & 0,813 & 0,837 \\
7 & Jarak Lokasi & 0,698 & 0,571 \\
8 & Kuantitas Pembelian & & 0,656 \\
\hline Cronbach alpha tingkat kepercayaan & & 0,746 \\
Cronbanch alpha tingkat kepentingan & & 0,848 \\
\hline
\end{tabular}

Rumus analisis Multiatribut Fishbein adalah sebagai berikut.

$A o=\sum_{i=1}^{n}$ ei. bi.

Keterangan :

Ao $=$ Sikap terhadap suatu objek

$\mathrm{b} i \quad=$ Kekuatan kepercayaan

$\mathrm{e} i \quad=$ Evaluasi terhadap atribut ke $-i$

$i \quad=$ Atribut $(1,2,3, \ldots, \mathrm{n})$

$\mathrm{n} \quad=$ Jumlah atribut yang dimiliki objek

Metode analisis regresi linear berganda digunakan untuk menganalisis faktor-faktor yang mempengaruhi pembelian telur ayam ras. Hal ini sesuai dengan penelitian Prasetyo, Sayekti dan Kasymir (2018) yang menggunakan analisis regresi untuk menganalisis faktor - faktor yang memengaruhi permintaan tempe di Kota Bandar komplementer

- Hal ini berarti bahwa keempat komoditas ini dapat menjadi pelengkap bagi rumah tangga dalam mengonsumsi telur ayam ras. Sebelum dilakukan analisis linear berganda, terlebih dulu dilakukan uji normalitas untuk melihat apakah data dalam penelitian ini berdistribusi secara normal serta uji multikolinearitas dan heteroskedastisitas. Model persamaan fungsi pembelian telur ayam ras pada penelitian ini adalah

$\mathrm{LnY}=\ln \mathrm{B}_{0}+\mathrm{B}_{1} \ln \mathrm{X}_{1}+\mathrm{ß}_{2} \ln \mathrm{X}_{2}+$ $\AA_{3} \ln X_{3}+\aleph_{4} \ln X_{4}+\aleph_{5} \ln X_{5}+\aleph_{6} \ln X_{6}+$ $\mathrm{B}_{7} \ln \mathrm{X}_{7}+\mathrm{B}_{8} \ln \mathrm{X}_{8}+\mathrm{B}_{9} \ln \mathrm{X}_{9}+$ $\mathrm{B}_{10} \ln \mathrm{X}_{10}+\mathrm{u}$

Keterangan :

$\mathrm{Y} \quad=$ Pembelian telur ayam ras ( $\mathrm{kg} /$ bulan)

$\beta_{0} \quad=$ Intersep

$\beta_{1}-\beta_{10}=$ Koefisien variabel bebas kuantitatif

$\mathrm{X} 1=$ Harga telur ayam $\operatorname{ras}(\mathrm{Rp} / \mathrm{kg})$
Lampung. Variabel terikat pada penelitian ini adalah pembelian telur ayam ras ( $\mathrm{kg} / \mathrm{bulan}$ ), sedangkan variabel - variabel bebas antara lain harga telur ayam ras, pendapatan rumah tangga, jumlah anggota rumah tangga, harga telur ayam kampung, daging ayam ras, daging sapi, tempe, tahu, ikan asin dan minyak goreng.

Harga telur ayam kampung, daging ayam ras, daging sapi, tempe, tahu, ikan asin, dan minyak goreng pada penelitian ini digunakan sebagai harga barang lain berdasarkan teori permintaan. Telur ayam kampung, daging ayam ras dan daging sapi pada penelitian ini dianggap sebagai barang subtitusi. Hal ini berarti bahwa ketiga komoditas ini dapat menjadi pengganti / alternatif bagi rumah tangga dalam mengonsumsi telur ayam ras. Tempe, tahu, ikan asin dan minyak goreng pada penelitian ini dianggap sebagai barang

$$
\begin{array}{ll}
\mathrm{X} 2 & =\text { Pendapatan rumah tangga }(\mathrm{Rp} / \mathrm{bulan}) \\
\mathrm{X} 3 & \text { = Jumlah anggota rumah tangga (jiwa) } \\
\mathrm{X} 4 & \text { = Harga telur ayam } \mathrm{kmpmp} \text { (Rp/kg) } \\
\mathrm{X} 5 & \text { = Harga daging ayam ras }(\mathrm{Rp} / \mathrm{kg}) \\
\mathrm{X} 6 & \text { = Harga daging sapi }(\mathrm{Rp} / \mathrm{kg}) \\
\mathrm{X} 7 & =\text { Harga tempe }(\mathrm{Rp} / \mathrm{kg}) \\
\mathrm{X} 8 & =\text { Harga tahu }(\mathrm{Rp} / \mathrm{kg}) \\
\mathrm{X} 9 & =\text { Harga ikan asin }(\mathrm{Rp} / \mathrm{kg}) \\
\mathrm{X} 10 & =\text { Harga minyak goreng }(\mathrm{Rp} / \mathrm{L}) \\
\mathrm{u} & =\text { Kesalahan pengganggu }
\end{array}
$$

\section{HASIL DAN PEMBAHASAN}

Responden dalam penelitian ini adalah ibu rumah tangga dan kepala keluarga dengan sebaran kelompok umur 27 - 59 tahun dan kelompok umur yang paling dominan adalah $41-50$ tahun sebanyak 54,67 persen atau sebanyak 41 dari total 75 responden. Pendapatan responden mulai dari Rp1.000.000 - Rp3000.0000 dan sebagian besar 
pendapatan responden adalah Rp1.000.000 Rp1.500.000.

\section{Tahapan Pengambilan Keputusan Pembelian Telur Ayam Ras}

Tahapan pengambilan keputusan pembelian telur ayam ras dibagi menjadi lima tahapan, yaitu pengenalan kebutuhan, pencarian informasi, evaluasi alternatif, keputusan pembelian dan evaluasi pasca pembelian. Hal ini sesuai dengan penelitian Putri, Sayekti dan Rangga (2019) yang membagi proses pengambilan keputusan dalam pemilihan pangan sayuran di Desa Gisting Atas ke dalam lima tahapan.

\section{Pengenalan Kebutuhan}

Proses pengenalan kebutuhan pembelian telur ayam ras dapat diliihat dari manfaat pemilihan lokasi, perasaan yang didapat jika tidak mengonsumsi telur ayam ras serta barang apa saja yang dibeli pada saat membeli telur ayam ras. Dapat diketahui bahwa mayoritas manfaat pemilihan lokasi yang dipilih oleh sebagian besar konsumen adalah harga yang murah yaitu sebesar 30,67 persen. Sebesar 62,67 persen kosumen mengaku merasa ada yang kurang jika tidak mengonsumsi telur ayam ras. Sebanyak 57,33 persen konsumen membeli telur ayam ras bersama dengan produk / komoditas lain seperti gula, minyak goreng, tahu dan tempe ketika melakukan pembelian telur ayam ras.

\section{Pencarian Informasi}

Proses pencarian informasi pembelian telur ayam ras pada penelitian ini dapat dilihat dari siapa yang pertama kali memberi tahu lokasi penjualan, siapa yang memengaruhi untuk memilih lokasi penjualan, darimana informasi harga telur di lokasi penjualan didapat dan apa yang menjadi fokus perhatian utama saat memilih lokasi penjualan telur. Pada penelitian ini diketahui bahwa konsumen tidak dipengaruhi oleh pihak lain dalam menentukan lokasi pembelian telur. Hal ini sesuai dengan penelitian Anggiasari, Indriani dan Endaryanto (2016) yang menyatakan bahwa yang memengaruhi pembelian sayur organik adalah diri sendiri. Pada penelitian ini juga didapatkan informasi mengenai lokasi penjualan telur ayam ras dan harga telur ayam di lokasi penjualan tersebut tidak diperoleh dari pihak lain dan harga telur menjadi fokus perhatian utama sebagian besar konsumen sebesar 28,00 persen. Hal ini berbeda dengan penelitian tentang beras siger oleh Parastry,
Lestari dan Prasmatiwi (2017) yang menyatakan bahwa sebagian besar konsumen mengetahui informasi beras Siger melalui keluarga.

\section{Evaluasi Alternatif}

Proses evaluasi alternatif pembelian telur ayam pada penelitian ini dapat dilihat dari atribut apa saja yang menjadi pertimbangan dalam memilih lokasi penjualan telur ayam ras dan apa yang akan dilakukan oleh anggota rumah tangga apabila telur ayam ras di lokasi penjualan yang dituju telah habis. Pada penelitian ini diketahui bahwa atribut yang paling banyak menjadi pertimbangan konsumen untuk membeli telur ayam ras di lokasi penjualan adalah harga telur ayam ras dengan jumlah sebanyak 29,33 persen. Hal yang dilakukan konsumen ketika ingin membeli telur ayam ras di lokasi penjualan yang dituju namun telah habis adalah dengan membeli di tempat atau lokasi pejualan lain. Hal ini sesuai dengan penelitian Anggiasari et al. (2016) yang menyatakan bahwa responden akan membeli sayur organik di tempat lain apabila swalayan chandra karang tutup.

\section{Keputusan Pembelian}

Proses keputusan pembelian telur ayam ras pada penelitian ini dapat dilihat dari berapa kali membeli telur ayam ras di lokasi penjualan dalam satu bulan, berapa volume / kuantitas pembelian telur ayam ras dalam satu bulan, seberapa sering mengonsumsi telur ayam ras, bagaimana memutuskan untuk membeli telur ayam ras di lokasi penjualan, bersama siapa biasanya membeli telur ayam ras di lokasi penjualan dan kapan biasanya membeli telur ayam ras di lokasi penjualan. Pada penelitian ini diketahui bahwa sebagian besar konsumen melakukan pembelian telur ayam ras adalah sebanyak empat kali dalam satu bulan. Dalam sekali pembelian, mayoritas konsumen melakukan pembelian sebanyak satu kilogram telur ayam ras. Konsumen sebagian besar membeli telur ayam ras secara terencana. Waktu yang biasa digunakan oleh anggota rumah tangga untuk membeli telur ayam ras paling banyak adalah pagi hari antara pukul 06.30 10.00 .

\section{Evaluasi Pasca Pembelian}

Proses evaluasi pasca pembelian telur ayam ras pada penelitian ini dapat dilihat dari apa yang dirasakan anggota rumah tangga setelah membeli telur ayam ras di lokasi penjualan, faktor apa saja 
Tabel 2. Sebaran kepentingan responden terhadap lokasi penjualan telur ayam ras.

\begin{tabular}{|c|c|c|c|c|c|c|c|}
\hline \multirow[b]{2}{*}{ No } & \multirow[b]{2}{*}{ Atribut } & \multicolumn{5}{|c|}{ Skor } & \multirow[b]{2}{*}{$\mathrm{Ei}$} \\
\hline & & \multicolumn{5}{|c|}{ (orang) } & \\
\hline 1 & Harga Telur & 50 & 25 & 0 & 0 & 0 & 4,67 \\
\hline 2 & Bobot Telur & 0 & 41 & 17 & 17 & 0 & 3,32 \\
\hline 3 & $\begin{array}{l}\text { Kebersihan } \\
\text { Telur }\end{array}$ & 3 & 38 & 30 & 4 & 0 & 3,53 \\
\hline 4 & $\begin{array}{l}\text { Kemasan } \\
\text { Telur }\end{array}$ & 0 & 0 & 41 & 25 & 9 & 2,43 \\
\hline 5 & $\begin{array}{l}\text { Kesukaan } \\
\text { terhadap } \\
\text { lokasi }\end{array}$ & 23 & 38 & 14 & 0 & 0 & 4,12 \\
\hline 6 & $\begin{array}{l}\text { Kebersihan } \\
\text { Lokasi }\end{array}$ & 0 & 0 & 39 & 26 & 10 & 2,39 \\
\hline 7 & Jarak Lokasi & 49 & 23 & 0 & 0 & 0 & 4,61 \\
\hline 8 & $\begin{array}{l}\text { Kuantitas } \\
\text { Pembelian }\end{array}$ & 4 & 40 & 31 & 0 & 0 & 3,64 \\
\hline
\end{tabular}

yang berpengaruh terhadap kepuasan dan ketidakpuasan dari pembelian telur ayam ras di lokasi penjualan dan atribut apa yang perlu mendapat perhatian dari lokasi penjualan telur. Pada penelitian ini diketahui bahwa mayoritas konsumen atau sebesar 85,33 persen konsumen merasa puas dengan pembelian telur ayam ras. Berdasarkan hasil dari wawancara, diketahui bahwa faktor utama yang menjadi pemuas konsumen dalam melakukan pembelian telur ayam ras adalah harga telur ayam ras dan jarak lokasi penjualan dengan rumah. Dapat dilihat juga sebanyak 11 konsmen atau sebesar 14,67 persen konsumen merasa tidak puas melakukan pembelian telur ayam ras di lokasi penjualan. Kebersihan lokasi dan kebersihan telur menjadi atribut yang membuat konsumen menjadi tidak puas saat melakukan pembelian telur ayam ras di lokasi penjualan.

Atribut yang perlu mendapatkan perhatian oleh penjual dalam menjual telur ayam ras di lokasi penjualan yang paling banyak dipilih oleh konsumen adalah adalah kebersihan lokasi dan kebersihan telur ayam ras yang dijual di lokasi tersebut. Hal ini karena konsumen menilai kebersihan lokasi dan kebersihan telur ayam ras yang dijual di dua lokasi yang sering dikunjungi berdasarkan wawancara, yaitu pasar tradisional dan warung kelontong masih terbilang kurang bersih.

\section{Sikap Rumah Tangga Prasejahtera dalam Membeli Telur Ayam Ras di Beberapa Lokasi Penjualan}

Pengukuran sikap pada penelitian ini menggunakan analisis Multiatribut Fishbein. Sikap konsumen yang dianalisis terdiri dari evaluasi tingkat kepentingan dan kepercayaan. Pada analisis sikap ini, responden terbagi menjadi tiga sesuai dengan lokasi yang paling sering dikunjungi untuk melakukan pembelian telur ayam ras. Jumlah responden yang memilih pasar tradisional, pasar modern dan warung kelontong berturut - turut berjumlah 32, 6 dan 37 responden. Pada Tabel 2 dan Tabel 3 dapat dilihat sebaran kepentingan (ei) dan kepercayaan responden (bi). Atribut yang digunakan pada penelitian ini yaitu harga telur, bobot telur, kebersihan telur, kemasan telur, kesukaan terhadap lokasi, kebersihan lokasi, jarak lokasi dan kuantitas pembelian. Atribut yang memiliki skor ei paling tinggi adalah harga telur ayam ras dan jarak lokasi dengan skor masing masing sebesar 4,67 dan 4,61.

Tabel 3. Sebaran skor kepercayaan (bi) responden terhadap lokasi penjualan telur ayam ras

\begin{tabular}{|c|c|c|c|c|c|c|c|c|c|c|c|c|c|c|c|c|c|c|c|}
\hline \multirow[b]{2}{*}{ No. } & \multirow[b]{2}{*}{ Atribut } & \multicolumn{6}{|c|}{ Pasar Tradisional } & \multicolumn{6}{|c|}{ Pasar Modern } & \multicolumn{6}{|c|}{ Warung Kelontong } \\
\hline & & 5 & 4 & $\begin{array}{c}3 \\
\text { ran }\end{array}$ & 2 & 1 & bi & 5 & 4 & $\begin{array}{l}3 \\
\text { ang }\end{array}$ & 2 & 1 & bi & 5 & 4 & $\begin{array}{c}3 \\
\text { rang }\end{array}$ & 2 & 1 & $\mathrm{Bi}$ \\
\hline 1 & Harga $\mathrm{T}$. & 13 & 19 & 0 & 0 & 0 & 4,41 & 0 & 0 & 0 & 3 & 3 & 1,50 & 0 & 15 & 19 & 3 & 0 & 3,32 \\
\hline 2 & Bobot T. & 0 & 24 & 8 & 0 & 0 & 3,75 & 0 & 4 & 2 & 0 & 0 & 3,67 & 0 & 17 & 14 & 6 & 0 & 3,30 \\
\hline 3 & $\begin{array}{l}\text { Kebersihan } \\
\text { Telur }\end{array}$ & 0 & 0 & 18 & 10 & 4 & 2,44 & 2 & 2 & 2 & 0 & 0 & 4,00 & 6 & 15 & 16 & 0 & 0 & 3,73 \\
\hline 4 & Kemasan & 0 & 0 & 16 & 14 & 2 & 2,44 & 2 & 2 & 2 & 0 & 0 & 4,00 & 0 & 6 & 18 & 13 & 0 & 2,81 \\
\hline 5 & $\begin{array}{l}\text { Kesukaan } \\
\text { lokasi }\end{array}$ & 1 & 15 & 16 & 0 & 0 & 3,53 & 0 & 2 & 4 & 0 & 0 & 3,33 & 4 & 13 & 20 & 0 & 0 & 3,57 \\
\hline 6 & $\begin{array}{l}\text { Kebersihan } \\
\text { Lokasi }\end{array}$ & 0 & 0 & 13 & 16 & 3 & 2,31 & 5 & 1 & 0 & 0 & 0 & 4,83 & 2 & 15 & 20 & 0 & 0 & 3,51 \\
\hline 7 & Jarak & 0 & 0 & 15 & 15 & 2 & 2,41 & 0 & 0 & 3 & 2 & 1 & 2,33 & 17 & 20 & 0 & 0 & 0 & 4,46 \\
\hline 8 & $\begin{array}{l}\text { Kuantitas } \\
\text { Pembelian }\end{array}$ & 0 & 17 & 15 & 0 & 0 & 3,53 & 0 & 0 & 4 & 1 & 1 & 2,50 & 0 & 0 & 20 & 12 & 5 & 2,41 \\
\hline Total & & & & & & & 24,81 & & & & & & 26,17 & & & & & & 27,11 \\
\hline
\end{tabular}


Tabel 4. Hasil analisis multiatribut sikap rumah tangga prasejahtera terhadap pembelian telur ayam ras di beberapa lokasi penjualan di Kota Bandar Lampung

\begin{tabular}{|c|c|c|c|c|c|c|c|c|}
\hline \multirow[t]{2}{*}{ No } & \multirow[t]{2}{*}{ Atribut } & \multirow{2}{*}{$\begin{array}{c}\text { Evaluasi Atribut } \\
\text { ei }\end{array}$} & \multicolumn{2}{|c|}{ Pasar Tradisional } & \multicolumn{2}{|c|}{$\begin{array}{c}\text { Pasar } \\
\text { Modern }\end{array}$} & \multicolumn{2}{|c|}{ Warung Kelontong } \\
\hline & & & bi & ei $x$ bi & bi & ei $x$ bi & bi & ei $x$ bi \\
\hline 1 & Harga Telur & 4,67 & 4,41 & $20,56^{1 \mathrm{a}}$ & 1,50 & $7,00^{\mathrm{c}}$ & 3,32 & $15,5^{2 \mathrm{~b}}$ \\
\hline 2 & Bobot Telur & 3,32 & 3,75 & $12,45^{\mathrm{a}}$ & 3,67 & $12,17^{3 \mathrm{~b}}$ & 3,30 & $10,95^{\mathrm{c}}$ \\
\hline 3 & Kebersihan Telur & 3,53 & 2,44 & $8,61^{\mathrm{c}}$ & 4,00 & $14,13^{1 \mathrm{a}}$ & 3,73 & $13,18^{b}$ \\
\hline 4 & Kemasan Telur & 2,43 & 2,44 & $5,92^{\mathrm{c}}$ & 4,00 & $9,71^{\mathrm{a}}$ & 2,81 & $6,82^{\mathrm{b}}$ \\
\hline 5 & $\begin{array}{l}\text { Kesukaan } \\
\text { terhadap lokasi }\end{array}$ & 4,12 & 3,53 & $14,55^{2 \mathrm{~b}}$ & 3,33 & $13,73^{2 \mathrm{c}}$ & 3,57 & $14,70^{3 \mathrm{a}}$ \\
\hline 6 & Kebersihan Lokasi & 2,39 & 2,31 & $5,52^{\mathrm{c}}$ & 4,83 & $11,54^{\mathrm{a}}$ & 3,51 & $8,39^{\mathrm{b}}$ \\
\hline 7 & Jarak Lokasi & 4,61 & 2,41 & $11,10^{\mathrm{b}}$ & 2,33 & $10,76^{\mathrm{c}}$ & 4,46 & $20,57^{1 \mathrm{a}}$ \\
\hline 8 & $\begin{array}{l}\text { Kuantitas } \\
\text { Pembelian }\end{array}$ & 3,64 & 3,53 & $12,85^{3 \mathrm{a}}$ & 2,50 & $9,10^{\mathrm{b}}$ & 2,41 & $8,76^{\mathrm{c}}$ \\
\hline & Ao ( ei.bi) & & & 91,56 & & 88,15 & & 98,87 \\
\hline
\end{tabular}

$\begin{array}{ll}\text { Keterangan : } \\ \text { ei } & =\text { skor kepentingan } \\ \text { bi } & =\text { skor kepercayaan } \\ \text { Ao } & =\text { skor sikap } \\ 1,2,3 & =\text { urutan atribut pada kolom yang sama } \\ \text { a,b,c } & =\text { urutan atribut pada baris yang sama }\end{array}$

Hal tersebut sesuai dengan penelitian mengenai pembelian ayam potong oleh Sianturi, Hasyim dan Situmorang (2016) yang menyatakan bahwa atribut harga daging ayam memiliki kepercayaan yang tinggi dari responden. Hal ini juga sesuai dengan penelitian Kamila, Prasetio dan Roessali (2019) yang menyatakan bahwa atribut beras yang paling memengaruhi sikap konsumen terhadap pembelian beras organik dan non organik adalah harga. Pada Tabel 3 dapat dilihat skor bi (kepercayaan) pada masing - masing atribut di tiga lokasi penjualan telur ayam ras. Sama seperti skor ei, skor bi didapatkan dengan cara menghitung hasil penjumlahan dari perkalian skor dan jumlah konsumen yang memilih skor tersebut lalu dibagi dengan total keseluruhan konsumen. Lokasi dengan skor bi paling tinggi adalah warung kelontong dan lokasi dengan skor bi paling rendah adalah pasar tradisional.

Pada Tabel 3 dapat dilihat bahwa atrbut yang memiliki skor bi tertinggi berbeda - beda di setiap lokasi penjualan telur ayam ras. Atribut yang memiliki skor bi paling tinggi di pasar tradisional adalah harga telur, di pasar modern adalah kebersihan lokasi sedangkan di warung kelontong adalah atribut jarak dari lokasi penjualan ke rumah responden.

Setelah mendapatkan skor ei dan bi dari setiap atribut, dilakukan analisis sikap Multiatribut Fishbein yang hasilnya dapat dilihat pada Tabel 4. Pada Tabel 4 dapat dilihat urutan dari skor Ao pada setiap atribut di ketiga lokasi penjualan telur ayam ras. Atribut yang mendapat skor sikap yang paling tinggi dan paling rendah di pasar tradisional, pasar modern dan warung kelontong berbeda.

Pada pasar tradisional skor sikap tertinggi adalah atribut harga telur yaitu 20,56; di pasar modern kebersihan telur memperoleh skor sikap tertinggi

sebesar 14,33; di warung kelontong jarak lokasi merupakan atribut yang memiliki skor sikap tertinggi yaitu sebesar 20,57. Skor sikap terendah di pasar tradisional, pasar modern dan warung kelontong adalah atribut kebersihan lokasi, harga telur dan kemasan telur.

Total skor sikap (Ao) pembelian telur ayam ras di pasar tradisional, pasar modern dan warung kelontong masing - masing adalah 91,56; 88,15 dan 98,87. Berdasarkan hasil perhitungan skor sikap tersebut, maka konsumen lebih menyukai membeli telur ayam ras di warung kelontong dibandingkan membeli telur ayam ras di pasar tradisional atau pasar modern.

\section{Faktor - Faktor yang Memengaruhi Rumah Tangga Prasejahtera dalam Melakukan Pembelian Telur Ayam Ras}

Pembelian telur ayam ras oleh rumah tangga dalam satu bulan mulai dari $2 \mathrm{~kg}-5 \mathrm{~kg}$ dengan harga beli Rp19.000,00-Rp24.000,00. Jumlah anggota rumah tangga yang paling banyak adalah tujuh orang dan yang paling sedikit adalah dua orang dengan pendapatan rumah tangga per bulan Rp1000.000,00-Rp3000.000,00. Pada penelitian ini, dilakukan uji normalitas data dengan menggunakan metode Kolmogorov Smirnov. 
Tabel 5. Hasil uji multikolinearitas dan uji heteroskedastisitas

\begin{tabular}{lc}
\hline \multicolumn{1}{c}{ Variabel } & VIF \\
\hline Harga telur ayam ras (X1) & 1,439 \\
Jumlah anggota rumah tangga (X2) & 1,671 \\
Pendapatan rumah tangga (X3) & 1,255 \\
Harga telur ayam kampung (X4) & 1,397 \\
Harga daging ayam ras (X5) & 1,165 \\
Harga daging sapi (X6) & 1,059 \\
Harga tahu (X7) & 1,120 \\
Harga tempe (X8) & 1,081 \\
Harga ikan asin (X9) & 1,220 \\
Harga minyak (X10) & 1,086 \\
\hline
\end{tabular}

Hasil dari uji normalitas data didapatkan hasil signifikansi sebesar 0,474 lebih dari 0,05 maka dapat disimpulkan bahwa sebaran data pada penelitian ini berdistribusi secara normal. Untuk mengetahui apakah pada data penelitian terdapat gejala multikolinearitas dan heteroskedastisitas, dilakukan uji multikolinearitas dan heteroskedastisitas. Berdasarkan Tabel 5 dapat dilihat hasil uji multikolinearitas dalam penelitian ini yaitu nilai dari VIF yang diperoleh kurang dari 10 sehingga tidak terdapat gejala multikolinearitas pada model penelitian dan berdasarkan uji heteroskedastisitas didapatkan nilai prob sebesar

Tabel 6. Hasil analisis regresi faktor - faktor yang memengaruhi pembelian telur ayam ras oleh rumah tangga prasejahtera di Kota Bandar Lampung

\begin{tabular}{lccc}
\hline \multicolumn{1}{c}{ Variabel } & K.regresi & t.hitung & Sig. \\
\hline Konstanta (c) & 9,552 & 0,416 & 0,162 \\
H. T. ayam ras (X1) & $-1,229 * * *$ & $-3,379$ & 0,001 \\
J. anggota RT (X2) & $0,656 * *$ & 7,788 & 0,000 \\
Pendapatan RT (X3) & $-0,041$ & $-0,445$ & 0,658 \\
H. T.A.kampung (X4) & 0,268 & 1,237 & 0,221 \\
H. D. ayam ras (X5) & 0,100 & 0,485 & 0,629 \\
H. D. sapi (X6) & 0,161 & 0,484 & 0,630 \\
Harga tahu (X7) & 0,040 & 0,360 & 0,720 \\
Harga tempe (X8) & $-0,029$ & $-0,344$ & 0,732 \\
Harga ikan asin (X9) & $-0,003$ & $-0,067$ & 0,947 \\
Harga minyak (X10) & $-0,188$ & $-1,024$ & 0,310 \\
\hline F - hitung & 17,529 & & 0,000 \\
R - squared & 0,733 & & \\
Adjusted R - squared & 0,691 & & \\
\hline Keterangan : & \\
*** Nyata dengan tingkat kepercayaan 99\% &
\end{tabular}

0,059 yang berarti tidak terdapat gejala heteroskedastisitas pada model penelitian karena nilai prob lebih dari 0,05 .

Hasil analisis regresi faktor-faktor yang memengaruhi pembelian telur ayam ras oleh rumah tangga prasejahtera di Kota Bandar Lampung dapat dilihat pada Tabel 6. Pada Tabel 6 dapat dilihat bahwa nilai $\mathrm{F}$ hitung pada model persamaan ini adalah 17,529 dengan signifikansi sebesar 0,000. Hal ini dapat diartikan bahwa semua variabel bebas pada penelitian ini secara bersama - sama berpengaruh nyata terhadap pembelian telur ayam ras oleh rumah tangga prasejahtera dengan tingkat kepercayaan sebesar 99 persen.

Harga telur ayam ras (X1) berpengaruh nyata negatif terhadap pembelian telur ayam ras dengan tingkat kepercayaan sebesar 99 persen. Hal ini berarti apabila terjadi kenaikan harga telur ayam ras sebesar satu persen maka pembelian telur ayam ras di Kota Bandar Lampung akan mengalami penurunan sebesar 1,229 persen. Hal ini sesuai dengan penelitian Awifa, Aji dan Supriono (2016)

yang menyatakan bahwa harga menjadi salah satu faktor yang memengaruhi konsumen dalam melakukan pembelian produk tahu di Kabupaten Jember. Jumlah anggota rumah tangga (X2) berpengaruh nyata positif dengan tingkat kepercayaan sebesar 99 persen. Hal ini berarti apabila terjadi kenaikan jumlah anggota rumah tangga sebesar satu persen maka pembelian telur ayam ras akan meningkat sebesar 0,656 persen. Hal ini sesuai dengan penelitian Rajagukguk, Sayekti dan Situmorang (2013) yang menyatakan bahwa jumlah anggota rumah tangga berpengaruh nyata terhadap jumlah pembelian buah jeruk.

\section{KESIMPULAN}

Hasil yang didapat dari penelitian ini adalah harga telur menjadi manfaat, fokus utama dan yang paling dipertimbangkan dalam melakukan pembelian telur ayam ras. Konsumen lebih menyukai melakukan pembelian telur ayam ras di warung kelontong dibandingkan pasar tradisional dan pasar modern. Faktor - faktor yang memengaruhi pembelian telur ayam ras adalah harga telur ayam ras, jumlah anggota rumah tangga dan lokasi favorit.

\section{DAFTAR PUSTAKA}

Andela WE, Endaryanto T, dan Adawiyah R. 2020. Sikap, pengambilan keputusan dan 
kepuasan konsumen terhadap agroindustri pie pisang di Kota Bandar Lampung. Jurnal Ilmu Ilmu Agribisnis, 8 (2) : 310 - 317.

https://jurnal.fp.unila.ac.id/index.php/JIA/artic le/view/4070/2965 [20 Januari 2021]

Anggiasari NM, Indriani Y, dan Endaryanto T. 2016. Sikap dan pengambilan keputusan pembelian sayuran organik oleh konsumen di Kota Bandar Lampung. Jurnal Ilmu Ilmu Agribisnis, 4 (4) : 391 - 397.

http://jurnal.fp.unila.ac.id/index.php/JIA/articl e/view/1521/1375 [23 Oktober 2019]

Awifa M, Aji JMM, dan Supriono A. 2016. Faktor - faktor yang mempengaruhi perilaku kosumen dalam pembelian produk tahu di Kabupaten Jember. $J P, 9(1): 30-40$. http://jurnaltrunojoyo.ac.id/pamator Oktober 2019]

BPS [Badan Pusat Statistik] Kota Bandar Lampung. 2018. Kota Bandar Lampung dalam Angka 2018. BPS Kota Bandar Lampung. Bandar Lampung.

BKKBN [Badan Kependudukan dan Keluarga Berencana Nasional] Provinsi Lampung. 2018. Rekapitulasi Hasil Pendataan Keluarga Tahun 2018. BKKBN Kota Bandar Lampung. Bandar Lampung.

Delila S, Indriani Y, dan Situmorang S. 2015. Pengambilan keputusan rumah tangga dalam membeli saus sambal botol di Bandar Lampung. Jurnal Ilmu Ilmu Agribisnis, 3 (1) $: 100-106$.

https://jurnal.fp.unila.ac.id/index.php/JIA/artic le/view/1023/928 [21 Januari 2021]

Engel JF, Blackwell RD, dan Miniard PW. 2006. Perilaku Konsumen (Alih Bahasa Budi Janto), Jilid II, Edisi Keenam. Binarpa Aksara. Jakarta.

Kamila F, Prasetio E, dan Roessali W. 2019. Analisis sikap konsumen pada pembelian beras di Kota Salatiga. Jurnal Sosial Ekonomi dan Kebijakan Pertanian, 3 (1) : 10 - 18. https://ejournal2.undip.ac.id/index.php/agrisoc ionomics [20 Oktober 2019]

Meriza F, Lestari DAH, dan Soelaiman A. 2016. Sikap dan kepuasan rumah tangga konsumen teh celup sari wangi dan sosro di Bandar Lampung. Jurnal Ilmu Ilmu Agribisnis, 4 (1) : $67-75$.

https://jurnal.fp.unila.ac.id/index.php/JIA/artic le/view/1216/1113 [20 Januari 2021]

Parastry A, Lestari DAH, dan Prasmatiwi FE. 2017. Pengambilan keputusan dan sikap konsumen rumah tangga dalam membeli beras siger toga dan mekar sari. Jurnal IlmuIlmu Agribisnis, 5 (2) : 192 - 199.

http://jurnal.fp.unila.ac.id/index.php/JIA/articl e/view/1658/1484 [21 Oktober 2019]

Prasetyo RE, Sayekti WD, dan Kasymir E. 2018. Tingkat kepuasan dan faktor - faktor yang mempengaruhi permintaan tempe oleh konsumen rumah tangga di KotaBandar Lampung. Jurnal Ilmu Ilmu Agribisnis, 6 (4) : $368-375$.

https://jurnal.fp.unila.ac.id/index.php/JIA/artic le/view/3056/2431 [20 Januari 2021]

Putri DW, Sayekti WD, dan Rangga KK. 2019. Pengambilan keputusan dalam pemilihan sayuran dan pola konsumsi sayuran rumah tangga petani sayuran di Desa Gisting Atas Kecamatan Gisting Kabupaten Tanggamus. Jurnal Ilmu Ilmu Agribisnis, 7 (3) : 420 - 427. https://jurnal.fp.unila.ac.id/index.php/JIA/artic le/view/3782/2783 [21 Januari 2021]

Rahmawati AN, Sayekti WD, dan Adawiyah R. 2018. Pengambilan keputusan dalam pemilihan pangan lokal olahan dan pola konsumsi pangan rumah tangga di Kota Metro. Jurnal Ilmu Ilmu Agribisnis, 6 (2) : $187-195$.

https://jurnal.fp.unila.ac.id/index.php/JIA/artic le/view/2785/2331 [21 Januari 2021]

Rajagukguk MJ, Sayekti WD, dan Situmorang S. 2013. Sikap dan pengambilan keputusan konsumen dalam membeli buah jeruk lokal dan buah jeruk impor di Bandar Lampung. Jurnal Ilmu Ilmu Agribisnis, 1 (4) : 351 - 357. http://jurnal.fp.unila.ac.id/index.php/JIA/articl e/view/713/655 [21 Oktober 2019]

Schiffman L dan Kanuk LL. 2007. Perilaku Konsumen Edisi Ke- 2. PT Indeks Gramedia. Jakarta.

Sianturi WJ, Hasyim AI, dan Situmorang S. 2016. Sikap dan pengambilan keputusan konsumen dalam membeli ayam potong di Kota Bandar Lampung. Jurnal Ilmu Ilmu Agribisnis, 4 (2) : $406-413$.

http://jurnal.fp.unila.ac.id/index.php/JIA/articl e/view/1523/1377 [20 Oktober 2019]

Sitorus LO, Murniati K, Rangga KK. 2020. Sikap dan kepuasan konsumen terhadap pembelian sate di Kota Bandar Lampung. Jurnal Ilmu Ilmu Agribisnis, 8 (2) : 303 - 309.

https://jurnal.fp.unila.ac.id/index.php/JIA/artic le/view/4068/2963 [20 Januari 2021]. 